\title{
Ethnic differences in thromboprophylaxis for COVID-19 patients: should they be considered?
}

\author{
Toshiaki Iba $^{1}$ (D) Jean Marie Connors ${ }^{2} \cdot$ Alex C. Spyropoulos $^{3} \cdot$ Hideo Wada $^{4} \cdot$ Jerrold H. Levy $^{5}$
}

Received: 16 September 2020 / Revised: 7 January 2021 / Accepted: 7 January 2021 / Published online: 20 January 2021

(c) Japanese Society of Hematology 2021

\begin{abstract}
Thromboembolic events contribute to morbidity and mortality in coronavirus disease 2019 (COVID-19). As a result, thromboprophylaxis using low-molecular-weight heparin (LMWH) is universally recommended for hospitalized patients based on multiple guidelines. However, ethnic differences with respect to thrombogenicity have been reported and the incidence of thromboembolic events is considered to be lower in the Asian population. Despite the importance of thromboprophylaxis, bleeding is also a side effect that should be considered. We examine the data relating to potential ethnic differences in thrombosis and bleeding in COVID-19. Although sufficient data is not yet available, current evidence does not oppose routine anticoagulant use and thromboprophylaxis using a standard dose of LMWH for admitted patients regardless of ethnicity based on our review.
\end{abstract}

Keywords COVID-19 · Thromboembolism · Deep vein thrombus · Thromboprophylaxis · Ethnic difference

\section{Introduction}

The severe acute respiratory syndrome coronavirus 2 (SARS-CoV-2) pandemic has posed a significant impact on morbidity and mortality in hospitalized patients. However, the incidence of death varies among different ethnic groups, as a New York state report notes that per-population coronavirus disease 2019 (COVID-19) fatality rates were $0.03 \%$, $0.18 \%$, and $0.12 \%$ for Caucasian, African-American, and Hispanic populations, respectively, and 5.38-fold disparity for African-American relative to Caucasian communities was observed [1]. The cause of ethnic disparities in mortality

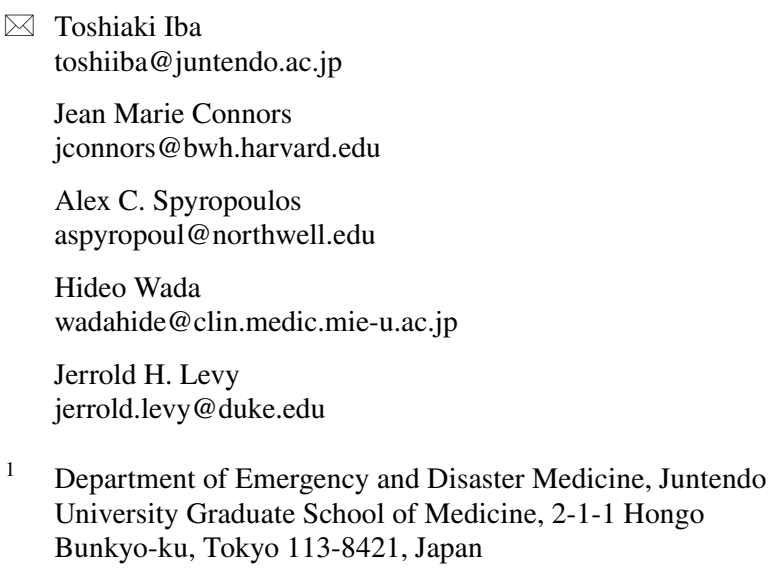

1 Department of Emergency and Disaster Medicine, Juntendo University Graduate School of Medicine, 2-1-1 Hongo Bunkyo-ku, Tokyo 113-8421, Japan

includes presence of other disease status such as hypertension, diabetes, however, different risks for thromboembolism among populations can be involved [2]. Apart from COVID19 , a survey performed in the USA reported the prevalence of venous thromboembolism (VTE) per 100,000 population was highest in African-American, followed by Caucasian, Hispanic, and other populations (Asians/Pacific Islanders) [3]. Thus, is the incidence of death and thrombotic complications among Asian COVID-19 patients lower than the other ethnicities? Although the clinical data regarding the thrombotic complications in the Asian population is still scarce, the question of whether the standard thromboprophylaxis

2 Harvard Medical School, Hematology Division Brigham and Women's Hospital, Boston, MA, USA

3 Department of Medicine, Anticoagulation and Clinical Thrombosis Services, The Institute for Health Innovations and Outcome Research, The Feinstein Institutes for Medical Research, The Donald and Barbara Zucker School of Medicine at Hofstra/Northwell, Northwell Health at Lenox Hill Hospital, New York, NY, USA

4 Department of General Medicine, Mie Prefectural General Medical Center, Yokkaichi, Mie, Japan

5 Department of Anesthesiology, Critical Care, and Surgery, Duke University School of Medicine, Durham, NC, USA 
is necessary to be applied equally to all populations should be considered. In this review, we examined the data about the inter-ethnic difference of thrombosis in COVID-19 and discuss the validity of universal thromboprophylaxis.

\section{The ethnic difference on mortality in COVID-19}

The death toll of COVID-19 reached 350,000 in August 2020 and roughly half was recorded in Europe and followed by North America. The count changes depending on the timing of disease spread but it still less than 10,000 deaths in South-East Asia and Western Pacific (https://covid19.who. int accessed Aug 8, 2020). The mortality difference in COVID-19 has been reported and the National Health Service (NHS) data of the United Kingdom revealed that Black and Asian groups are at increased risk of infection and death from COVID-19. The age and region adjusted NIH data suggested a lower risk of death for White Irish and White British ethnic groups, but increased risk of death for Black African (3.24, 95\% confidence interval [CI] 2.90-3.62), Indian (1.70, 95\% CI 1.56-1.85), and other minor ethnic populations [4]. Another study also from the UK that utilized more than 10,000 COVID-19-related death records demonstrated that age-sex adjusted hospital death rates for Black COVID-19 patients are 2.17-times higher compared to those in White, and 1.95-times higher than Asian patients [5]. A similar but larger survey was performed in Brazil. Baqui et al. [6] performed a cross-sectional study on 11,321 patients and reported, Pardo (mixed ethnicity) and Black Brazilian ethnicity with COVID-19 had a higher risk of mortality (hazard ratio [HR] 1.45, 95\% CI 1.33-1.58 for Pardo; HR 1.32, 95\% CI 1.15-1.52 for Black Brazilians) compared with White Brazilians. However, the association between the Black race and increased mortality is still uncertain because the elimination of factors regarding inequity in health, health care access, and quality of care is not easy [7]. Price-Haywood [8] collected the data from 3481 COVID-19 patients from the integrated-delivery health system in Louisiana, USA and demonstrated that race, increasing age, a higher score on the comorbidity index, public insurance (Medicare or Medicaid), residence in a low-income area, and obesity were associated with increased odds of hospital admission. On the other hand, in adjusted time-to-event analyses, variables that were associated with higher in-hospital mortality were old age and elevated respiratory rate at presentation, elevated lactate levels, creatinine, or procalcitonin, or low platelet or lymphocyte counts, and Black race was not associated with higher mortality. A similar result was also reported from Ohio, USA [9]. Thus, the relationship between ethnicity and disease severity or death still remains to be clarified.

\section{The ethnic disparities of deep vein thrombosis and thromboembolism}

Even before the COVID-19 pandemic, the prevalence of VTE was high in the United States and reported to be 100 per 100,000 persons each year. Approximately one-third of patients with symptomatic VTE manifest pulmonary embolism (PE), whereas two-thirds manifest deep vein thrombosis (DVT) alone [10]. The prevalence of thromboembolism differs considerably among different ethnic and population groups, and it is significantly higher in African Americans and Caucasians compared to Hispanic and Asian-Pacific Islanders [11]. In Japanese, the incidence of VTE is reportedly approximately one-eighth of North Americans [12, 13]. Factor V Leiden mutation, deficiencies of protein $\mathrm{C}$, protein $\mathrm{S}$, and antithrombin are the assumed hereditary relevant factors. Hyperhomocysteinemia and elevated levels of factors I, VIII and XI, are the other possible hereditary risk factors [14]. However, the difference may not be arisen from the ethnic difference but due to the lack of well-designed studies as well as nonstandardized survey designs [15]. As a matter of fact, the incidence of VTE in Asian countries has risen recently and doubled in the past 10 years $[12,13]$. This could be attributed to lifestyle changes, ageing population, increasing awareness of VTE [15]. For the comparison of the interracial incidence, it is difficult to control lifestyle factors such as diet or exercise, and eliminate the environmental factors, but Nicole Tran et al. [16] examined more than 60,000 residents in northern California demonstrated the adjusted HR for VTE in Asian ethnic was 0.5 to the Caucasians (Chinese 0.5, Japanese 0.5, Filipino 0.6, and South Asian 0.9). In addition, a population-based study examined the risk of postpartum VTE in the US reported African American and Asian women had a greater and lower risk of VTE compared to the Caucasian women (adjusted odds ratio [OR] 1.50 and 0.67 , respectively) [17]. After all, the ethnic difference in VTE incidence still remains unclear, but it could be lower in the Asian countries compared to than Western countries [18, 19].

\section{Thrombosis in COVID-19 and ethnic differences}

Thromboembolic events in COVID-19 is a major concern for clinicians. Santoliquido et al. [20] performed a systematic screening of lower limb vein by compression ultrasonography in non-ICU hospitalized COVID-19 patients and reported the incidence of DVT was $11.9 \%$. However, the incidence considerably varies among the 
reports and the prevalence of VTE ranges from 3 to $85 \%$ [21]. The wide range of this incidence probably arisen from the diversity in study design (systematic or selected screening), setting (ICU vs general wards), intervention (uniform or individual thromboprophylaxis), and timing of the examination. Therefore, inter-race differences should be examined in a similar condition. In the ICU setting, a French study examined critically ill patients using complete duplex ultrasound and reported the overall VTE rate of $69 \%$ [22]. Another study also performed in France reported a DVT rate of $65 \%$ at admission, and $79 \%$ at $48 \mathrm{~h}$ after ICU admission [23]. As for the Asian ethnicity, a Chinese study performed in COVID-19 ICU patients reported 46-85.4\% incidence of DVT [24] (Table 1). Although the studies performed in ICU generally include only a small number of cases, the incidence of DVT in Chinese patients does not seem to be lower than that of Caucasians. However, we should be careful about translating these results since many of the ICU patients are sedated and the patients do not complain the symptom appropriately. Therefore, the routine screening is recommended in this setting.

\section{Mechanism of thrombus formation in COVID-19}

Understanding the pathophysiology of COVID-19-associated coagulopathy is important to assess the necessity of thromboprophylaxis. However, the underlying mechanisms are multifactorial [31, 32]. Recent studies emphasize the importance of the endothelial injury caused by SARS-CoV-2 infection leading to micro- and macrothrombosis in COVID19 [33]. The relative significance of DVT/PE in the development of respiratory failure or critical illness may be decreasing based on recent reports [34]. The endotheliopathy of COVID-19 causes vascular endothelial dysfunction, loss of its anticoagulant properties, and is associated with other factors contributing to the hypercoagulability that include

Table 1 The incidence of deep vein thrombosis in ICU patients detected by ultrasonography reported from Asia and Europe

\begin{tabular}{|c|c|c|c|c|c|c|}
\hline Country & Patient/setting & Number & Measure & $\begin{array}{l}\text { Timing of assess- } \\
\text { ment }\end{array}$ & DVT prophylaxis & Incidence of DVT \\
\hline China [24] & Patients in ICU & 48 & $\begin{array}{l}\text { Compression ultra- } \\
\text { sonography }\end{array}$ & Not assessed & $\begin{array}{l}\text { Standard LMWH } \\
\text { thromboprophy- } \\
\text { laxis }\end{array}$ & $\begin{array}{l}\text { DVT; } 85.4 \% \\
\text { Proximal DVT; } 75 \% \\
\text { Distal DVT; } 10.4 \%\end{array}$ \\
\hline China [25] & $\begin{array}{l}\text { Critically ill patients } \\
\text { in ICU }\end{array}$ & 88 & $\begin{array}{l}\text { Compression ultra- } \\
\text { sonography }\end{array}$ & $\begin{array}{l}\text { More than } 1 \text { week } \\
\text { after ICU admis- } \\
\text { sion }\end{array}$ & $\begin{array}{l}\text { Standard LMWH } \\
\text { thromboprophy- } \\
\text { laxis }\end{array}$ & $\begin{array}{l}\text { DVT; } 46 \% \\
\text { Proximal DVT; } 9.1 \% \\
\text { Distal DVT; } 46 \%\end{array}$ \\
\hline China [26] & $\begin{array}{l}\text { Critically ill patients } \\
\text { managed by inten- } \\
\text { sivists }\end{array}$ & 143 & $\begin{array}{l}\text { Ultrasonography } \\
\text { scanning }\end{array}$ & Not assessed & $\begin{array}{l}37.1 \% \text { Received } \\
\text { standard LMWH } \\
\text { and others no } \\
\text { thromboprophy- } \\
\text { laxis }\end{array}$ & $\begin{array}{l}\text { DVT } 46.1 \% \\
\text { Proximal DVT; } 16.1 \% \\
\text { Distal DVT; } 30.1 \%\end{array}$ \\
\hline France [22] & Patients in ICU & 26 & $\begin{array}{l}\text { Duplex ultrasonog- } \\
\text { raphy }\end{array}$ & $\begin{array}{l}\text { Day } 1-7 \text { after } \\
\text { admission }\end{array}$ & $\begin{array}{l}\text { Standard or } \\
\text { therapeutic dose of } \\
\text { LMWH or unfrac- } \\
\text { tionated heparin }\end{array}$ & $\begin{array}{l}\text { DVT; } 69 \% \\
\text { Proximal DVT; } 26 \% \\
\text { Distal DVT; } 68 \%\end{array}$ \\
\hline France [23] & $\begin{array}{l}\text { Patients with ARDS } \\
\text { and treated in ICU }\end{array}$ & 34 & $\begin{array}{l}\text { Duplex ultrasonog- } \\
\text { raphy }\end{array}$ & $48 \mathrm{~h}$ after admission & $\begin{array}{l}\text { Standard thrombo- } \\
\text { prophylaxis }\end{array}$ & $\begin{array}{l}\text { DVT } 79 \% \\
\text { Proximal DVT; } 16.1 \% \\
\text { Distal DVT; } 30.1 \%\end{array}$ \\
\hline Switzerland [27] & $\begin{array}{l}\text { Critically ill patients } \\
\text { in ICU }\end{array}$ & 25 & $\begin{array}{l}\text { Ultrasonography } \\
\text { screening }\end{array}$ & $\begin{array}{l}\text { Day } 5-10 \text { after } \\
\text { admission }\end{array}$ & $\begin{array}{l}\text { Continuous } \\
\text { intravenous infu- } \\
\text { sion of heparin } \\
(15,000 \mathrm{IU} / 24 \mathrm{~h})\end{array}$ & $\begin{array}{l}\text { DVT/VTE; } 32 \% \\
\text { proximal DVT; } 24 \% \\
\text { pulmonary embolism; } \\
20 \%\end{array}$ \\
\hline $\begin{array}{l}\text { The Netherlands } \\
\text { [28] }\end{array}$ & Patients in ICU & 75 & $\begin{array}{l}\text { Ultrasonography } \\
\text { screening }\end{array}$ & $\begin{array}{l}\text { Day } 7-21 \text { after } \\
\text { admission }\end{array}$ & $\begin{array}{c}\text { Standard to double } \\
\text { dose of LMWH }\end{array}$ & $\begin{array}{l}\text { DVT Day } 7 ; 26 \% \text {, Day } \\
\text { 14; } 47 \% \text {, Day 21; } \\
59 \%\end{array}$ \\
\hline $\begin{array}{l}\text { The Netherlands } \\
\text { [29] }\end{array}$ & Patients in ICU & 184 & $\begin{array}{l}\text { Ultrasonography } \\
\text { screening }\end{array}$ & During ICU stay & $\begin{array}{l}\text { Standard or higher } \\
\text { dose thrombo- } \\
\text { prophylaxis }\end{array}$ & $\begin{array}{l}\text { Thrombosis } 31 \% \\
\text { (VTE in } 27 \% \text {, } \\
\text { arterial thrombosis } \\
3.7 \% \text { ) }\end{array}$ \\
\hline Italy [30] & Patients in ICU & 61 & $\begin{array}{l}\text { Compression ultra- } \\
\text { sonography }\end{array}$ & During ICU stay & $\begin{array}{l}\text { Standard or } \\
\text { therapeutic dose of } \\
\text { LMWH }\end{array}$ & Thrombosis $27.6 \%$ \\
\hline
\end{tabular}

$D V T$ deep vein thrombosis, VTE venous thromboembolism, $L M W H$ low-molecular-weight heparin 
increased release of von Willebrand factor (VWF), Factor VIII, and angiopoietin 2, increased fibrinogen, presence of antiphospholipid antibodies, and dysregulated inflammation. As a result, the loss of endothelial function along with a marked systemic hypercoagulability is estimated to be the major cause of pulmonary microthrombotic injury and respiratory failure [35]. It is noteworthy that AfricanAmericans are reported to have higher circulating levels of VWF, Factor VIII and fibrinogen [36]. The differences in endothelial function and molecular mechanisms of thrombosis risk due to genetic factors may lead to the ethnic disparities in COVID-19-associated thrombosis [37]. With respect to the comparison of endothelial dysfunction in Asians and other ethnicities, little data are available to make any conclusions. Investigations as to the levels of VWF, Factor VIII, and fibrinogen in response to infection in various races are expected to provide the data that clarify the ethnic disparity of COVID-19-associated thrombosis.

\section{Thromboprophylaxis in COVID-19}

There are two aims for thromboprophylaxis in COVID-19, suppression of microthrombus formation and prevention of macrothrombosis. The International Society on Thrombosis and Haemostasis (ISTH) released guidelines for thromboprophylaxis in COVID-19 and recommend universal standard prophylaxis using LMWH unless contraindication for all hospitalized patients [38]. Following this recommendation, other international organization such as World Health Organization (WHO) propose a similar recommendation [39]. Although thromboprophylaxis is effective, the incidence is still high with standard prophylaxis and more intensive prophylaxis is expected. However, the bleeding adverse event is a serious problem and the net effect of prophylaxis with higher dose is still unknown [40]. ISTH recommendations are conservative for a more aggressive thromboprophylaxis, and only $30 \%$ of experts agreed on the use of intermediate-dose of LMWH in hospitalized COVID-19 patients, compared to $50 \%$ of experts for intermediate-dose LMWH for the high-risk ICU patients [41]. A recent small but prospective study reported the efficacy of higher intensity regimen in critically ill patients and the application of this type of prophylaxis needs to be determined in ongoing randomized trials [42].

Anticoagulation to reverse organ dysfunction in COVID19 may be different, although its efficacy is unknown. Russo et al. [43] analyzed the data from 192 consecutive Italian patients who underwent pre-admission antithrombotic therapy and reported that adjusted regression analyses showed no difference in ARDS on admission, or death during hospitalization between patients treated with antiplatelets or anticoagulants. This observation suggests that thromboprophylaxis does not have sufficient effects on microthrombosis prevention and protective effect in the progression of COVID-19. In contrast, another observational study from the USA revealed a better outcome in patients treated with anticoagulation compared to the patients treated without anticoagulation. The in-hospital mortality in the patients who required mechanical ventilation and treated with anticoagulation was $29.1 \%$, while that of the patients treated without anticoagulants was $62.7 \%$ [44]. This difference may not be achieved only from VTE prevention but also from the effect of maintenance of microcirculation. With respect to the bleeding adverse events, the incidence of major bleeding was $1.9 \%$ in the patients treated without anticoagulants and $3 \%$ in those who received anticoagulants $(P=0.2)$ [44]. A Chinese study also reported a better prognosis in severe cases with coagulopathy or with markedly elevated D-dimer [45]. The effects of anticoagulation on endothelial damage and microcirculation are the topics of future study.

\section{Bleeding adverse events with pharmacologic thromboprophylaxis}

Based on initial reports, the incidence of bleeding has been considered to be low in COVID-19 supporting the concept of potentially higher dose pharmacological thromboprophylaxis. However, since Asian people are estimated to be more susceptible to anticoagulation compared to the other ethnicities, the application of universal thromboprophylaxis may pose increased risk for Asian populations. Thus, comparing the bleeding incidence in COVID-19 among different populations is challenging. Currently, many of the admitted patients receive thromboprophylaxis, therefore, it is almost impossible to divide the bleeding that relates to COVID-19 itself from that relates to the anticoagulation. One previous large-scale observational study from the USA reported the incidence of $1.9 \%$ in the patients without anticoagulation and $3.0 \%$ in the patients with anticoagulation [46]. Table 2 summarized the incidence of bleeding reported from various countries, and the incidence in China does not seem to be higher than that in western countries.

The awareness of different bleeding susceptibility with anticoagulant therapy has arisen based on the experience of warfarin. Warfarin requirement is highest in Caucasians, lower in Hispanics, and lowest in Asians because of the differences in genetic background [50]. It is also known that the bleeding risk of antiplatelets is also higher in the Asian population [51]. In contrast, such differences are not seen with direct oral anticoagulants (DOACs) and the DOACs are more preferable alternatives for Asian patients [52]. As for the heparin and LMWH in COVID-19, it is too early to conclude that there is no ethnic difference in bleeding rates, 
Table 2 The incidence of bleedings in COVID-19 patients

\begin{tabular}{|c|c|c|c|c|c|}
\hline Country & Patient/setting & Number & DVT prophylaxis & $\begin{array}{l}\text { Incidence of thrombotic } \\
\text { events }\end{array}$ & Incidence of bleeding events \\
\hline USA [48] & $\begin{array}{l}\text { Critically ill; } 144 \\
\text { Non-critically ill; } 256\end{array}$ & 400 & $\begin{array}{l}\text { Standard LMWH thrombo- } \\
\text { prophylaxis }\end{array}$ & $9.5 \%$ & $4.8 \%$ (major bleeding; $2.3 \%$ ) \\
\hline USA [44] & Hospitalized patients & 2773 & $\begin{array}{l}786(28 \%) \text { Received } \\
\text { systemic anticoagulation } \\
\text { (oral, subcutaneous, or } \\
\text { intravenous forms) }\end{array}$ & Not assessed & $\begin{array}{l}\text { Without anticoagulation; } \\
1.9 \% \\
\text { With anticoagulation; } 3.0 \%\end{array}$ \\
\hline Spain [46] & Patients in non-ICU & 156 & $\begin{array}{l}\text { Standard LMWH thrombo- } \\
\text { prophylaxis }\end{array}$ & $14.7 \%$ & $1.9 \%$ \\
\hline China [49] & $\begin{array}{l}\text { Hospitalized patients } \\
\text { (critically ill 10.9\%) }\end{array}$ & 138 & $\begin{array}{l}41(30.1 \%) \text { Received stand- } \\
\text { ard thromboprophylaxis }\end{array}$ & $2.9 \%$ & $4.3 \%$ \\
\hline China [25] & $\begin{array}{l}\text { Critically ill patients in } \\
\text { ICU }\end{array}$ & 88 & $\begin{array}{l}\text { Standard LMWH thrombo- } \\
\text { prophylaxis }\end{array}$ & $46 \%$ & $6 \%$ \\
\hline France [47] & Patients in ICU & 92 & $\begin{array}{l}\text { Standard or therapeutic } \\
\text { dose of LMWH or } \\
\text { unfractionated heparin }\end{array}$ & $\begin{array}{l}40 \% \text { (venous; } 79 \% \text {, arterial } \\
21 \% \text { ) }\end{array}$ & $\begin{array}{l}21 \% \text { (deep muscle; } 23 \%, \\
\text { gastro-intestinal } 14 \%, \\
\text { intracranial; } 9 \% \text { ) }\end{array}$ \\
\hline Switzerland [27] & $\begin{array}{l}\text { Critically ill patients in } \\
\text { ICU }\end{array}$ & 25 & $\begin{array}{l}\text { Continuous intravenous } \\
\text { infusion of heparin } \\
(15,000 \mathrm{IU} / 24 \mathrm{~h})\end{array}$ & DVT/VTE; 32\% & $\begin{array}{l}\text { Major bleeding; } 0 \% \\
\text { Minor bleeding; } 8 \%\end{array}$ \\
\hline
\end{tabular}

$D V T$ deep vein thrombosis, $V T E$ venous thromboembolism, $L M W H$ low-molecular-weight heparin

but the present data does not seem to support the idea that the Asians are more likely to bleed than Caucasians and other ethnics.

\section{Recommendation of the thromboprophylaxis for COVID-19 in various patient groups}

Postoperative anticoagulant therapy was proven to reduce the risk of VTE and has become routine therapy in Western countries. In contrast, postoperative thromboprophylaxis has not been done routinely in many Asian countries [53-55]. Certainly, a similar approach may not be adequate in COVID-19 because the background of the inter-ethnic risk/ benefits difference of the anticoagulation is still uncertain. To reduce harm from COVID-19 associated VTE, the ISTH consequently released the guidance for VTE prevention [38, 41], and collaboratively worked with the WHO to share the knowledge for global VTE management (https://www.isth. org/news/517212/A-Systematic-Approach-for-ManagingVenous-Thromboembolism-in-Patients-with-COVID-19. htm). One of the objects of this projects is highlight the importance of a systematic approach to VTE prevention, diagnosis and treatment for patients with COVID-19 worldwide. However, ethnic differences have not been considered in these approaches.

Other than the effects on VTE prevention, anticoagulants are also expected to provide benefit for the treatment of microthrombosis. Several studies have investigated the effect of heparins, especially unfractionated heparin, in patients with bacterial sepsis-associated DIC. The reported meta-analyses, showed a trend of reduced 28-day mortality but also revealed a trend toward increased risk of bleeding. Again, no racial disparity was examined in these analyses [56-58]. The net effect of heparin on microthrombosis in COVID-19 is still unclear and further study in different ethnicities is warranted.

\section{Summary}

Important observations include the presence of microthrombosis and microangiopathy in the lung associated with hemorrhage in COVID-19. These findings significantly contributed to disease severity and death. The endothelial damage and microthrombosis contribute to the typical feature of diffuse alveolar damage, including hyaline membranes and fibrin deposition in the alveolus that are present even in patients who are not in critical condition. The development of large thrombi and embolization accelerate the respiratory insufficiency and ultimately to death. Thus, the suppression of microclot formation and prevention of thromboembolism are required as key benefits of anticoagulant therapy. Of note are the potential ethnic disparities that can exist in the thrombogenicity and bleeding risk of COVID-19. Therapeutic considerations for thromboprophylaxis should potentially be made separately based on the data constructed upon individual races although there is at present no data that support this idea. Rather the current evidence does not 
oppose the same regimen to Asian populations as they are recommended to Western populations. Future protocols for thromboprophylaxis should be determined based on the balance between the benefits and the risk of bleeding in various ethnicities.

Acknowledgements This work was supported in part by a Grant-inAid for Special Research in Subsidies for ordinary expenses of private schools from The Promotion and Mutual Aid Corporation for Private Schools of Japan.

\section{Compliance with ethical standards}

Conflict of interest Iba T. has received a research grant from Japan Blood Products Organization and JIMRO. Connors JM. receives personal fees from Bristol-Meyer Squibb, Abbott, Portola, and research funding to the institution from CSL Behring. Spyropoulos AC. reports research grants and consulting from Janssen Research \& Development LLC, Bayer, Portola, Boehringer Ingelheim, and the ATLAS group. Wada $\mathrm{H}$ received grants and personal fees from Asahi Kasei Pharma Corporation and Japan Blood Products Organization. Levy JH serves on the Steering or Advisory Committees for Instrumentation Laboratories, Merck, Octapharma, and Leading Biosciences.

\section{References}

1. Holtgrave DR, Barranco MA, Tesoriero JM, Blog DS, Rosenberg ES. Assessing racial and ethnic disparities using a COVID19 outcomes continuum for New York State. Ann Epidemiol. 2020;48:9-14.

2. Fogarty H, Townsend L, Ni Cheallaigh C, Bergin C, MartinLoeches I, Browne P, et al. COVID19 coagulopathy in Caucasian patients. Br J Haematol. 2020;189(6):1044-9.

3. Deitelzweig SB, Lin J, Johnson BH, Schulman KL. Venous thromboembolism in the US: does race matter? J Thromb Thrombolysis. 2011;31(2):133-8.

4. Aldridge RW, Lewer D, Katikireddi SV, Mathur R, Pathak N, Burns R, et al. Black, Asian and Minority Ethnic groups in England are at increased risk of death from COVID-19: indirect standardisation of NHS mortality data. Wellcome Open Res. 2020;5:88.

5. Williamson EJ, Walker AJ, Bhaskaran K, Bacon S, Bates C, Morton CE, et al. OpenSAFELY: factors associated with COVID-19 death in 17 million patients. Nature. 2020. https://doi.org/10.1038/ s41586-020-2521-4.

6. Baqui P, Bica I, Marra V, Ercole A, van der Schaar M. Ethnic and regional variations in hospital mortality from COVID-19 in Brazil: a cross-sectional observational study. Lancet Glob Health. 2020;8(8):e1018-26.

7. Evans MK. Covid's color line-infectious disease, inequity, and racial justice. N Engl J Med. 2020;383(5):408-10.

8. Price-Haywood EG, Burton J, Fort D, Seoane L. Hospitalization and mortality among black patients and white patients with Covid19. N Engl J Med. 2020;382(26):2534-43.

9. Suleyman G, Fadel RA, Malette KM, Hammond C, Abdulla H, Entz A, et al. Clinical characteristics and morbidity associated with coronavirus disease 2019 in a series of patients in metropolitan detroit. JAMA Netw Open. 2020;3(6):e2012270.

10. White RH. The epidemiology of venous thromboembolism. Circulation. 2003;107(23 Suppl 1):I4-8.

11. Shen JJ, Cochran CR, Mazurenko O, Moseley CB, Shan G, Mukalian R, et al. Racial and insurance status disparities in patient safety indicators among hospitalized patients. Ethn Dis. 2016;26(3):443-52.

12. Guidelines for diagnosis, treatment and prevention of pulmonary thromboembolism and deep vein thrombosis (JCS 2017) https ://j-circ.or.jp/old/guideline/pdf/JCS2017_ito_h.pdf

13. Wang KL, Yap ES, Goto S, Zhang S, Siu CW, Chiang CE. The diagnosis and treatment of venous thromboembolism in asian patients. Thromb J. 2018;16:4.

14. Kearon C. Epidemiology of venous thromboembolism. Semin Vasc Med. 2001;1(1):7-26.

15. Liew NC, Chang YH, Choi G, Chu PH, Gao X, Gibbs H, et al. Asian venous thromboembolism guidelines: prevention of venous thromboembolism. Int Angiol. 2012;31(6):501-16.

16. Nicole Tran H, Klatsky AL. Lower risk of venous thromboembolism in multiple Asian ethnic groups. Prev Med Rep. 2019;13:268-9.

17. Blondon M, Harrington LB, Righini M, Boehlen F, Bounameaux $\mathrm{H}$, Smith NL. Racial and ethnic differences in the risk of postpartum venous thromboembolism: a population-based, case-control study. J Thromb Haemost. 2014;12(12):2002-9.

18. Jang MJ, Bang SM, Oh D. Incidence of venous thromboembolism in Korea: from the Health Insurance Review and Assessment Service database. J Thromb Haemost. 2011;9:85-91.

19. JCS. Guidelines for the diagnosis, treatment and prevention of pulmonary thromboembolism and deep vein thrombosis (JCS 2009). Circ J. 2011;75:1258-81.

20. Santoliquido A, Porfidia A, Nesci A, De Matteis G, Marrone $\mathrm{G}$, Porceddu $\mathrm{E}$, et al. Incidence of deep vein thrombosis among non-ICU patients hospitalized for COVID-19 despite pharmacological thromboprophylaxis. J Thromb Haemost. 2020. https://doi. org/10.1111/jth.14992.

21. Marchandot B, Trimaille A, Curtiaud A, Matsushita K, Jesel L, Morel O. Thromboprophylaxis: balancing evidence and experience during the COVID-19 pandemic. J Thromb Thrombolysis. 2020;21:1-10.

22. Llitjos JF, Leclerc M, Chochois C, Monsallier JM, Ramakers M, Auvray M, et al. High incidence of venous thromboembolic events in anticoagulated severe COVID-19 patients. J Thromb Haemost. 2020;18(7):1743-6.

23. Nahum J, Morichau-Beauchant T, Daviaud F, Echegut P, Fichet J, Maillet JM, et al. Venous thrombosis among critically ill patients with coronavirus disease 2019 (COVID-19). JAMA Netw Open. 2020;3(5):e2010478.

24. Ren B, Yan F, Deng Z, Zhang S, Xiao L, Wu M, et al. Extremely high incidence of lower extremity deep venous thrombosis in 48 patients with severe COVID-19 in Wuhan. Circulation. 2020;142(2):181-3.

25. Chen S, Zhang D, Zheng T, Yu Y, Jiang J. DVT incidence and risk factors in critically ill patients with COVID-19. J Thromb Thrombolysis. 2020;30:1-7.

26. Zhang L, Feng X, Zhang D, Jiang C, Mei H, Wang J, et al. Deep vein thrombosis in hospitalized patients with COVID-19 in Wuhan, China: prevalence, risk factors, and outcome. Circulation. 2020;142(2):114-28.

27. Longchamp A, Longchamp J, Manzocchi-Besson S, Whiting L, Haller C, Jeanneret S, et al. Venous thromboembolism in critically Ill patients with COVID-19: Results of a screening study for deep vein thrombosis. Res Pract Thromb Haemost. 2020;4(5):842-7.

28. Middeldorp S, Coppens M, van Haaps TF, Foppen M, Vlaar AP, Müller MCA, et al. Incidence of venous thromboembolism in hospitalized patients with COVID-19. J Thromb Haemost. 2020. https ://doi.org/10.1111/jth.14888.

29. Klok FA, Kruip MJHA, van der Meer NJM, Arbous MS, Gommers DAMPJ, Kant KM, et al. Incidence of thrombotic complications in critically ill ICU patients with COVID-19. Thromb Res. 2020;191:145-7. 
30. Lodigiani C, Iapichino G, Carenzo L, Cecconi M, Ferrazzi P, Sebastian T, et al. Venous and arterial thromboembolic complications in COVID-19 patients admitted to an academic hospital in Milan Italy. Thromb Res. 2020;191:9-14.

31. Levi M, Thachil J, Iba T, Levy JH. Coagulation abnormalities and thrombosis in patients with COVID-19. Lancet Haematol. 2020;7(6):e438-40.

32. Iba T, Levy JH, Connors JM, Warkentin TE, Thachil J, Levi M. The unique characteristics of COVID-19 coagulopathy. Crit Care. 2020;24(1):360.

33. Goshua G, Pine AB, Meizlish ML, Chang CH, Zhang H, Bahel $\mathrm{P}$, et al. Endotheliopathy in COVID-19-associated coagulopathy: evidence from a single-centre, cross-sectional study. Lancet Haematol. 2020;7(8):e575-82.

34. Kollias A, Kyriakoulis KG, Stergiou GS, Syrigos K. Heterogeneity in reporting venous thromboembolic phenotypes in COVID19: methodological issues and clinical implications. Br J Haematol. 2020. https://doi.org/10.1111/bjh.16993.

35. Escher R, Breakey N, Lämmle B. ADAMTS13 activity, von Willebrand factor, factor VIII and D-dimers in COVID-19 inpatients. Thromb Res. 2020;192:174-5.

36. Lutsey PL, Cushman M, Steffen LM, Green D, Barr RG, Herrington $\mathrm{D}$, et al. Plasma hemostatic factors and endothelial markers in four racial/ethnic groups: the MESA study. J Thromb Haemost. 2006;4(12):2629-35.

37. Ramasamy R, Milne K, Bell D, Stoneham S, Chevassut T. Molecular mechanisms for thrombosis risk in Black people: a role in excess mortality from COVID-19. Br J Haematol. 2020;190(2): e78-80.

38. Thachil J, Tang N, Gando S, Falanga A, Cattaneo M, Levi M, et al. ISTH interim guidance on recognition and management of coagulopathy in COVID-19. J Thromb Haemost. 2020;18(5):1023-6.

39. Thachil J, Juffermans NP, Ranucci M, Connors JM, Warkentin TE, Ortel TL, et al. ISTH DIC subcommittee communication on anticoagulation in COVID-19. J Thromb Haemost. 2020;18(9):2138-44.

40. Gavioli EM, Sikorska G, Man A, Rana J, Vider E. Current perspectives of anticoagulation in patients with COVID-19. J Cardiovasc Pharmacol. 2020. https://doi.org/10.1097/FJC.0000000000 000861

41. Spyropoulos AC, Levy JH, Ageno W, Connors JM, Hunt BJ, Iba $\mathrm{T}$, et al. Clinical guidance on the diagnosis, prevention, and treatment of venous thromboembolism in hospitalized patients with COVID-19. J Thromb Haemost. 2020;18(8):1859-65.

42. Taccone FS, Gevenois PA, Peluso L, Pletchette Z, Lheureux O, Brasseur A, et al. Higher intensity thromboprophylaxis regimens and pulmonary embolism in critically Ill coronavirus disease 2019 patients. Crit Care Med. 2020;48(11):e1087-90.

43. Russo V, Di Maio M, Attena E, Silverio A, Scudiero F, Celentani $\mathrm{D}$, et al. Clinical impact of pre-admission antithrombotic therapy in hospitalized patients with COVID-19: a multicenter observational study. Pharmacol Res. 2020;159:104965.

44. Paranjpe I, Fuster V, Lala A, Russak AJ, Glicksberg BS, Levin MA, et al. Association of treatment dose anticoagulation with inhospital survival among hospitalized patients with COVID-19. J Am Coll Cardiol. 2020;76(1):122-4.

45. Tang N, Bai H, Chen X, Gong J, Li D, Sun Z. Anticoagulant treatment is associated with decreased mortality in severe coronavirus disease 2019 patients with coagulopathy. J Thromb Haemost. 2020;18(5):1094-9.
46. Demelo-Rodríguez P, Cervilla-Muñoz E, Ordieres-Ortega L, Parra-Virto A, Toledano-Macías M, Toledo-Samaniego N, et al. Incidence of asymptomatic deep vein thrombosis in patients with COVID-19 pneumonia and elevated D-dimer levels. Thromb Res. 2020;192:23-6.

47. Fraissé M, Logre E, Pajot O, Mentec H, Plantefève G, Contou D. Thrombotic and hemorrhagic events in critically ill COVID19 patients: a French monocenter retrospective study. Crit Care. 2020;24(1):275.

48. Al-Samkari H, Karp Leaf RS, Dzik WH, Carlson JCT, Fogerty AE, Waheed A, et al. COVID-19 and coagulation: bleeding and thrombotic manifestations of SARS-CoV-2 infection. Blood. 2020;136(4):489-500.

49. Xu JF, Wang L, Zhao L, Li F, Liu J, Zhang L, et al. Risk assessment of venous thromboembolism and bleeding in COVID-19 patients. Res Sqare. 2020. https://doi.org/10.21203/rs.3.rs-18340 /v1.

50. Mak M, Lam C, Pineda SJ, Lou M, Xu LY, Meeks C, et al. Pharmacogenetics of warfarin in a diverse patient population. J Cardiovasc Pharmacol Ther. 2019;24(6):521-33.

51. Hoshino T, Sissani L, Labreuche J, Bousser MG, Chamorro A, Fisher M, et al. Non-cardioembolic stroke/transient ischaemic attack in Asians and non-Asians: a post-hoc analysis of the PERFORM study. Eur Stroke J. 2019;4(1):65-74.

52. Yamashita Y, Morimoto T, Toyota T, Shiomi H, Makiyama T, Ono K, et al. Asian patients versus non-Asian patients in the efficacy and safety of direct oral anticoagulants relative to vitamin $\mathrm{K}$ antagonist for venous thromboembolism: a systemic review and meta-analysis. Thromb Res. 2018;166:37-42.

53. Cohen AT, Tapson VF, Bergmann JF, Goldhaber SZ, Kakkar AK, Deslandes B, et al. Venous thromboembolism risk and prophylaxis in the acute hospital care setting (ENDORSE study): a multinational crosssectional study. Lancet. 2008;371:387-94.

54. Falck-Ytter Y, Francis CW, Johanson NA, Curley C, Dahl OE, Schulman S, et al. Prevention of VTE in orthopedic surgery patients: antithrombotic therapy and prevention of thrombosis, 9th ed: American College of Chest Physicians Evidence-Based Clinical Practice Guidelines. Chest. 2012;141:e278S-325S.

55. Gould MK, Garcia DA, Wren SM, Karanicolas PJ, Arcelus JI, Heit JA, et al. Prevention of VTE in nonorthopedic surgical patients: antithrombotic therapy and prevention of thrombosis, 9th ed: American College of Chest Physicians Evidence- Based Clinical Practice Guidelines. Chest. 2012;141:e227S - e277.

56. Fan Y, Jiang M, Gong D, Zou C. Efficacy and safety of low-molecular-weight heparin in patients with sepsis: a meta-analysis of randomized controlled trials. Sci Rep. 2016;6:25984.

57. Wang C, Chi C, Guo L, Wang X, Guo L, Sun J, et al. Heparin therapy reduces 28 -day mortality in adult severe sepsis patients: a systematic review and meta-analysis. Crit Care. 2014;18(5):563.

58. Zarychanski R, Abou-Setta AM, Kanji S, Turgeon AF, Kumar A, Houston DS, et al. The efficacy and safety of heparin in patients with sepsis: a systematic review and metaanalysis. Crit Care Med. 2015;43(3):511-8.

Publisher's Note Springer Nature remains neutral with regard to jurisdictional claims in published maps and institutional affiliations. 